no evidence, past or present, that the green woodpecker has been at native of Scotland.

In naming the brown trout Salmo trutta, I followed the considered opinion of such an expert in fish nomenclature as Mr. C. T. Regan, of the British Museum (Natural History); my statement regarding the success of the introduction of Loch Leven irout to New Zealand did not pretend to record any first achieved sucress, and as it stands is correct; and the two "caricatures, and poor at that," specified by your reviewer happen to be reproduced from photographs of specimens mounted by skilled taxidermists, and now exhibited in the Roval Scottish Museum.

JAMES RITCHE.

I should be sorry indeed if, in reviewing his book, I had given Dr. Ritchie the impression that I undervalued it as a contribution to prehistoric research. I did no more than express difficulty in accompanying Dr. Ritchie: to the full extent of his conclusions, and surprise that, from first to last, he takes no notice of the 25 -ft. beach.

I admit that I cxpressed myself too positively in saying that it was "clear that the land ice was srinding over all after the elevation which formed the younger $25 \mathrm{ft}$. beach." But many years of personal examination of the features of the Scottish seaboard have left on ny mind a strong impression that some agent more powerful than sub-aerial denudation has masked or obliterated by far the greater extem of the 5o-ft. beach. Such an agent misy have been subsidence, glacial action, or "trail" (earth thawing and flowing after prolonged freezing, as in the "earthglaciers" of the Rockies).

Some support to this view may be found in the late Prof. James Geikie's Munro lectures, "Intiquity of Man in "Europe," 1914: "At the head of Loch Torridon well-formed terminal moraines rest directly upon the 45-50-ft. beach" (p. 273).

Prof. Geikie considered (p. 279) that the formation of that beach was followed by "partial subsidence," and continued:

"IVe cannot actually demonstrate that snowfields and glaciers reappeared at this stage. . . Nevertheless, we are not without evidence suggestive of the appearance at this time of inconsiderable glaciers amongst our highest mountains. These glaciers undoubtedly existed at a later date than the glaciers that dropped their moraines on the $4.5-50-\mathrm{ft}$. beach. It is therefore only reasonable to infer that the hishlevel corrie glaciers in question were probably contemporaneous with the formation of the $25-\mathrm{ft}$. to $30-\mathrm{ft}$. beach."

The occurrence of kitchen-middens on the $5^{0-f t}$. beach can scarcely be taken to prove the presence of man when the sea stood at that level. On the summit of the Fell of Barhullion in Wigtownshire, $45^{\circ} \mathrm{ft}$. above the present sea-level and $1 \frac{1}{2}$ miles distant from the nearest beach, are the remains of a fortified enclosure. The refuse-heap of this encampment contains a large quantity of limpet-shells. I och Spouts, in Ayrshire, is on high ground two or three miles from the sea. Dr. Munro has recorded that when the crannog in that swamp was explored, in the midden were found "large quantities of the shells of whelks. limpets, and hazel-nuts" ("Iake-dwellings of Europe," p. 420).

Prof. Geikie cited the discovery of a canoe near Perth as evidence that Neolithic man was in orrupation when the sea washed the $50 . \mathrm{ft}$. beach. I have been unable to find any detailed record of the finding of this canoe, and if. as Prof. Geikie says, it was made of pine. I should hold that to be incomnatible with verv high antiquity. Having taken part in the excavation of many crannogs. I have never seen anv submerged timber, except oak and yew, that retained a firmer consistency than cheese.

Dr. Ritchie expresses the opinion that "there seems to be . . no evidence, yast or present, that the green woodpectier has been a native of Scotland." In Wallis's "History of Northumber. land," I769, vol. i., p. 319, it is stated that this species "has been observed in some of our valewoods, but is not common. It was frequent in Dilston Park before the wood was cut down." Two instances of its occurrence in the valley of the Tweed are recorded in Mr. Evans's "Fauna of the 'Tweed Area," p. 100 . Dr. Ritchie seems to be in error in attributing to Newton and Yarrell the use of the name " woodwall" as a seneric term for all three British species of wosdpecker. Yarrell strictly confines it to the green workpecker, though he admits that Villushby and Ray use the term in a looser sense: ("British Birds," third edition, vol. ii., p. I49), while Newton merely mentions it among the popular names for woodpeckers in general. The great and lesser spotted woodpeckers do not utter any song or bell-like note, and it seems fairly clear that it is the sreen woolpecker that figures in the ballad of Robin Hood (cura Ritson) :

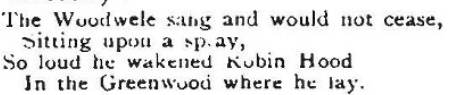

It is probable that the sreen woodpectier, yaffle, or woodwale disappeared frum Scotland with the forest that sheltered it.

THE REVIEWER.

\section{Literature for Men of Letters and Science in Russia.}

AT the beginnings of this year an appeal was issued for funds to enable at certain number of scientific and literary publications to be sent to the House of Science and the House of Literature: in Petursburs, where the remmant of tile intellectual life of Russia is mostly congregated. The British Comnictee for diding Men of leetters and science in that country has assured itself th:t such publications will reach the ir destination, and has made arrangements tor their transmission. There are probably many authors who would be? willings to send copits of their works in the form cit excerpts or otherwise to Russian worlsers who have been cut off from the outside world since the revolution. The British Committee will be slad to receive any such books or papers of a non-political type and to send them to Petersburg. It cannot guarantee delivery to individuals, but it can ensure that publications will reach the Houses of I,iterature and Science. Parcels for transmission should be addressed to the above Committer, care of Messrs. Wm. Dawson and Sons, Ltd., Continental 1)epartment, Rolls Buildings, Fetter Lane, li.l.4. L. F. Schus'rer.

British Science Guild Offices, 6 John Street, Adelphi, London, IV.C..2, January 26.

\section{The Mild Weather.}

Arropos of Mr. Charles Harding's letter (Nature, January 20), one result of the extraordinary weather in the south of England since the third weel of December was that on January 24 I saw forty or fifty plants in flower of the minute Crucifer (Hutchinsia petraea) on limestone screes close to Bristol. Some of the seedlings were 2 in. high, with five or six flowering heads and with secd-pods already developed. Last year a few were in flower on February 12, but even this is remarliably early, for March-ipril is the usual time in the district for this rare plant, and most of the books give MarchMay. On January 5 I saw a hazel in full blossom between Gunnersbury and Kew.

H StunRt THOMPSON.

5 Westbourne Place, Clifton, January 30. 